\title{
A NEW SPECIES OF CULEX (MELANOCONION) FROM SOUTHERN BRAZIL (DIPTERA: CULICIDAE)*
}

Oswaldo Paulo Forattini**

Maria Anice Mureb Sallum**

FORATTINI, O.P. \& SAIJUM, M.A.M. Nova espécie de Culex (Melanoconion) da região meridional do Brasil (Diptera: Culicidae). Rev. Saúde públ., S. Paulo 19:171-82, 1985.

RESUMO: Descreve-se nova espécie, denominada Culex (Melanoconion) ribeirensis, da região meridional do Brasil, incluindo localidades dos Estados de São Paulo e do Rio de Janeiro. A descrição inclui as formas adultas, pupal e larval, e é acompanhada de ilustrações representativas desses estádios, além do aspecto de um criadouro natural. Apresentam-se também alguns dados sobre a distribuição geográfica, até agora conhecida, e do comportamento dessa espécie.

UNITERMOS: Culex (Melanoconion) ribeirensis. Culicidae. Insetos vetores.

\section{INTRODUCTION}

In the course of ecological studies on mosquitoes and mosquito-borne infections in the Ribeira Valley, in the Southern region of S. Paulo State, Brazil, a species of Culex (Melanoconion) presented remarkable doininance in the several types of collection techniques utilized. Initially it was identified as $C x$. crybda, and some data on its behaviour were reported under this name (Forattini and coll. ${ }^{1}, 1981$ ). Studies made in another similar regions, also showed the presence of this mosquito, identified as the same manner (Oliveira ${ }^{4}, 1984$ ).

More detailed studies led to the conclusion that it was an as yet undescribed species, distinct from crybda and others which are close to it. So we take this opportunity to describe and name this new species.

For the description the terminology utilized was that of Harbach and Knight ${ }^{2}$ (1980), with some modifications made by Harbach, Peyton and Harrison ${ }^{3}$ (1984), the general lines of whose description have been followed in this paper.
Culex (Melanoconion) ribeirensis, sp. $\mathrm{n}$.

Culex (Melanoconion) epanastasis of Sirivanakarn and Jakob5, 1979:139.

Adult. - A species resembling Culex adamesi and $C x$. crybda with no remarkable differences in the male genitalia, but differing in other details of the adult, besides in some related to pupa and larva.

FEMALE. - Body dark almost entirely clothed by mainly dark brown scales. Head. - Antenna dark, mean length $2.06 \mathrm{~mm}$ ( $\pm=0.12$ ); flagellum whorls normally with 6 setae. Proboscis completely covered by dark scales, mean length $1.78 \mathrm{~mm}( \pm=0.13)$. Maxillary palpus entirely coated with dark scales, mean length $0.40 \mathrm{~mm}$ ( $\pm=0.03$ ), about 0.22 of the proboscis length; frequently with a small and variously developed supernumerary article at the apex of the fourth palpomere (Fig. 3 MPlp). Vertex (Fig. $1 \mathrm{~A}, \mathrm{~B})$ with narrow falcate scales; in the lateral sides of the region these scales are predominantely clear, a little median

- Supported by Grant n.० MVR-BR-2-84-6 - National Academy of Sciences, USA.

* Of the Department of Epidemiology of the School of Public Health, S. Paulo University - Av. Dr. Arnaldo, 715 - 01255 - São Paulo, SP - Brazil. 
FORATTINI, O.P. \& SALLUM, M.A.M. A new species of Culex (Melanoconion) from Southern Brazil (Diptera: Culicidae). Rev. Saúde públ., S. Paulo, 19:171-82, 1985.

area with other falcate scales predominantely dark; a little lateral set of broad dingy clear scales; forked scales dark; ocular and interocular setae lengthy, dark or with golden sheen. Cibarial armature (Fig. 1 C, D, E, F and Fig. $3 \mathrm{CA}, \mathrm{Ct}$ ). - Cibarial ridge concave, with almost 20 or a few more cibarial teeth with sizes gradually smaller in a lateral direction; cibarial teeth fold shaped like pan tiles, borne on the transverse ridge, dorsally bearing a spatulated hyaline rod slightly serrulated at apex, and with a smaller prickle followed by a short and light longitudinal ridge appearing as a little crest situated between the cibarial teeth. Cibarial dome as a nearly circular outline concave cap entirely built by superficial sharp pointed denticles. Thorax. - Integument dark brown. Scutum entirely covereb by fine narrow bronzy sheen dark scales, with some clear ones variously disposed, in a patchy manner, on the anterior promontory, the prescutal suture, ante and supraalar and prescutellar areas; infrequently specimens may show an entirely dark clothed scutum; scutal setae developed and bronzy shining; acrostichal setae absent. Scutellar scales looking like the scutal one, frequently mixed with some clear others. Antepronotum without scales, with bronzy setae disposed almost in a row on the anterolateral surface. Postpronotum with narrow dark scales, as the scutum ones, sometimes with a small number of clear others situated near the spiracle region; posterodorsal margin with 5-8 long dark setae. Pleural sclerites with similar tonality or a little clear than the scutum; proepisternum, postspiracular area, prealar knob, anteroinferior region of mesokatepisternum, inferior and superior regions of mesepimeron, all of them with dark areas pattern, but leaving the median mesepimeron area crossed by a clear band of varying breadth. Pleura with a characteristic patch of broad spatulate whitish scales situated on the upper corner and posteroinferior margin of the mesokatepisternum with whitish scales (Fig. 1H, I); pleural setae dark brown and golden shining, a few darker ones in the prealar knob; setae 15-21 upper proepisternals, 5-12 prealars, 7-11 upper mesokatepisternals, 11-14 lower mesokatepisternals, 15-21 upper mesepimerals and one, or, occasionally, two lower mesepimerals. Wing. - Mean length $3.25 \mathrm{~mm}( \pm=0.27)$; scales dark; subcosta reach costa at the same level or a little before the $\mathbf{R}_{2}+3$ furcation. Dorsal scaling (Fig. $1 \mathrm{G}$ ); appressed spatulate scales on costa, subcosta, $R, R_{1}, \mathrm{mcu}, \mathrm{CuA}$ and 0.5 basal of $M$ and of $1 \mathrm{~A}$; linear plume scales on $R_{8}, R_{2+3}$, proximally $R_{4+5}, M$ and $M_{1+2}$; inclined, narrow spatulate scales on $R_{1}, R_{8}, R_{2+3}, R_{2}, R_{3}, R_{4+5}, M_{1+2}$, $\mathrm{M}_{1}, \mathrm{M}_{2}, \mathrm{CuA}$ and $1 \mathrm{~A}$; remigium with appressed spatulate scales and 3 distal strong setae. Ventral scaling (Fig. $1 \mathrm{~J}$ ): appressed spatulate scales on costa, subcosta, $\mathbf{R}_{\mathrm{s}}, \mathrm{R}_{2+3}, \mathrm{R}_{2}, \mathrm{R}_{3}, \mathrm{M}_{1}$ and $\mathrm{M}_{2+3}$; linear plume scales on proximally $R_{1}$, $R_{s}, R_{2+3}$, proximally $R_{t+5}$, distally $M$, $\mathrm{M}_{1+2}, \mathrm{M}_{3+4}, \mathrm{CuA}$ after $\mathrm{mcu}$, and $1 \mathrm{~A}$; inclined, narrow spatulate scales on distally $R_{1}, R_{2}, R_{3}, M_{1}, M_{2}, M_{3+4}$, distally $\mathrm{CuA}$ and $1 \mathrm{~A}$, proximally, both $\mathrm{CuA}$ and $1 \mathrm{~A}$ devoid of scales. Halter. Scabellum and pedicel pale; capitellum entirely covered by clear scales. Legs. Entirely dark-scaled, without pale band pattern; posteroventral surface of femora pale-scaled. Abdomen. - Terga dark-scaled with basolateral pale scales, sometimes becoming basal pale bands of various breadth. Sterna basally covered by pale scales and distally by dark ones. Genitalia (Fig. 2). - Tergum X narrow in middle and widened at posterolateral margin where there are 10 or a little more setae on each side. Upper vaginal lip distinct and narrow, lower one indistinct; insula indistinct, with about 8-10 clustered insular setae. Upper vaginal screlite as an inverted $\mathrm{U}$-shaped thic- 
FORATTINI, O.P. \& SALLUM, M.A.M. A new species of Culex (Melanoconion) from Southern Brazil (Diptera: Culicidae). Rev. Saúde públ., S. Paulo, 19:171-82, 1985.

kened at base. Postgenital lobe short, triangular or trapezoidal shaped, distally narrowed, with 7-10 setae on either midline side, mostly on ventral surface.

MALE. - Like female except for the sexual differences presented as follow. Head. - Antenna strongly plumose with length about $2.0 \mathrm{~mm}$. Maxillary palpus entirely dark, length about 2.6 $\mathrm{mm}$, exceeding the proboscis tip through the distal fourth of palpomere 4 and all palpomere 5 length; palpomeres 4 and 5 entirely covered by strong setae; palpomere 3 with strong setae only in the distal region. Abdomen. - Tergum II entirely dark or with a little patch of pale scales in the median basal area; terga III-VII with basal pale-scaled band; tergum VIII (ventral in position) without pale scales and with a deep Vshaped median posterior emargination (Fig. 2), sternum VIII (dorsal in position) with basolateral pale spots. Genitalia (Fig. 2). - Tergal IX lobes small, cone-shaped, widely separated and bearing slender setae. Gonocoxite stocky and ovoid shaped, outer margin convex, inner moderately concave; ventrolateral surface with dark strongly developed setae, scattered scales on the ventrolateral surface base, mesal surface with some variable rows of slender setae extending from base to subapical lobe level, another patch of smaller ones situated below this lobe; lateral surface with a patch of short scattered setae at the apical region corresponding to the level of the subapical lobe; subapical lobe clearly divided, divisions clearly separated; proximal division undivided, lengthened, with an apical infundibular expansion partially covering the two, $a$ and $b$ setae insertions, which are long, enlarged and slightly sinous, another hooked-falciform seta in subdistal position, two smaller subbasal and some basal others sparse short setae; distal division with two arms each bearing apical inserted setae, the basal one with 1 long hooked $h$ and 2 saberlike $s$, one of which is larger than the other, the apical arm with 2 long saberlike $s$ setae and 3 flat setae $f$ with differente lengths one of them much more short than the two others. Gonostylus slender, curved, moderate distally widened, crest slightly wrinkled before the apical beak; gonostylar claw folded leaf-like. Phallosome with lateral plates and aedeagal sclerites equivalent in size and length, separated by a not clearly delimited low quitinized striped area, giving to the whole an open $S$ appearance at lateral view; lateral plate with ventral, lateral and dorsal processes, the ventral one short, triangular and laterally bent, the lateral process longer, slender, tapered, pointed at apex and dorsolaterally directed, the dorsal process stout and situated at base of lateral plate; aedeagal sclerite broad and curved in lateral view, with anterior margin thickened, dorsal end appearing a thick right angle, connected with the other by a dorsal aedeagal bridge; paramere and basal plate roughly triangular shaped and with blunted end. Proctiger elongate; paraprocto distally narrowed and basally expanded where it is articulated with the basal plate and the posterolateral margin of the tergum $X$, crown with 8-10 flat rectangular simple blades; cercal sclerite narrow, elongate, looking like a stripe lightly quitinized; cercal setae very small; tergum $\mathrm{X}$ somewhat rectangular and concavo-convex.

PUPA (Fig. 3). - General aspect of chaetotaxy as figured. Cephalothorax. Slightly pigmented. Seta 1-CT lengthy, double; 2-CT with 3 or 4 branches; 3 -CT similar to 1-CT, simple or double; 4-CT double or with 3 branches; 5-CT with 2-4 branches; 6-CT simple; 7-CT with 2-3 branches; 8-CT with 2-4 branches; 9-CT with 2-3 branches; 10-CT fanlike with 8-10 dendritic branches; 11-CT lengthy, double; $12-\mathrm{CT}$ usually triple, 
FORATTINI, O.P. \& SALLUM, M.A.M. A new species of Culex (Melanoconion) from Southern Brazil Diptera: Culicidae). Rev. Saúde públ,, S. Paulo, 19:171-82, 1985.

infrequently with 4 branches. Trumpet. - Heavily pigmented funnel-shaped; index 6.3-7.7; tracheoid area with same tone, extending about 0.5 from base; pinna large, prolonged with the meatus slit forming a whole triangular outlined; pinna-slit length corresponding to a little more than 0.5 of that the trumpet one. Abdomen. - Pigmented like the cephalothorax, a little more heavely on the anterior margins of terga II-VII; the VIII with more diffused pigmentation; length 2.48-3.03 mm. Segments I-III: seta 4-I with 3-5 branches; 1-II multiple with 20-30 branches; 1-III with 6-10 branches; 3-I-III double; 5-III with 3-6 branches; 6-III lengthy, double. Segments IV-VIII: seta 1-IV with 7-11 branches; $1-\mathrm{V}$ with $5-8$ branches; $1-\mathrm{VI}$ with $2-5$ branches; 1 -VII double or triple; 5-IV with $6-9$ branches; $5-\mathrm{V}$ with 4-6 branches; 5-VI with 2-4 branches; 6-IV-VI lengthy, double; 9-VII strong and simple; 9-VIII similar to 9-VII, inserted on the posterolateral angle. Genital lobe. - Lightly pigmented in female, darker in male; length about $0.12-0.13 \mathrm{~mm}$ in female, $0.26 \mathrm{~mm}$ in male. Paddle. - Diffusively pigmented; midrib developed and heavily pigmented; buttress developed at base and darker than the paddle general tone; margins smooth; length $0.60-0.79 \mathrm{~mm}$, width $0.45-0.50 \mathrm{~mm}$, index 1.30-1.58. Setae 1-P and 2-P simple and slender.

LARVA (Fig. 4). - General aspect of chaetotaxy as figured. Head. - Wider than long; length $0.68-0.69 \mathrm{~mm}$, width 0.93-0.97 $\mathrm{mm}$; diffusively pigmented, apart from some little defined areas symmetrically situated on the posterior part of dorsal apotome and on lateralia. Labiogula longer than broad, broader posteriorly; hypostomal suture complete, extended from the posterior tentorial pit to the collar. Collar poorly developed, heavily pigmented. Dorsomentum with a median tooth larger than the 7 lateral ones disposed at either side. Seta 1-C spiniform, dark; 2-C absent; $3-\mathrm{C}$ very small; 4-C developed with 3-5 branches; 5-C greatly developed fanlike with 6-7 branches heavily aciculate; 6-C lengthy, simple aciculate; 8-C small with 4-7 branches; 9-C similar to 8-C, with 7-10 branches; $10-\mathrm{C}$ with 3-4 slender branches; 11-C strong, with 5-8 branches; 13-C developed with 5-8 branches, inserted posteriorly to $11-\mathrm{C} ; 14-\mathrm{C}$ slender double or triple; $15-\mathrm{C}$ with 3-5 branches, inserted posteriorly to 14-C. Antenna. - Length $0.51-0.57 \mathrm{~mm}$; heavily pigmented, more densely spiny on the proximal part of flagellum and lesser on the laterodistal one near seta 1-A. Scape developed; pedicel weak and hardly perceptible. Antennal puncture distinct. Seta 1-A developed, with 28-30 aciculate branches, inserted 0.77-0.81 from the base; setae 2, 3-A lengthy, dark, straighter, sharpened, apically inserted. Thorax. - Integument hyaline, covered with tiny spicules, more conspicuous on the prothorax. Setae 1-3-P and 9-12-P,M,T inserted on common moderately pigmented tubercle. Prothorax. - Setae 1,2-P lengthy, simple aciculate; 3-P about 0.25 of the 1,2-P length, with 6-11 branches; 4-P double, lengthy, aciculate; 5,6-P simple, lengthy; 7-P with 5-7 branches; 8-P with 3-6 branches. Mesothorax. Seta 1-M fanlike developed, with 5-11 slightly aciculate branches; 2-M smaller than 1-M, with 3-6 branches. Metathorax. - Seta 1-T small, with 3-4 slender branches; 3-T with 6-8 branches; 13-T similar to 1-M, with 8-13 branches. Abdomen. - Integument hyaline, entirely smooth. Setae 6-I,II, 7-I and 2,3VIII inserted on moderately pigmented tubercles. Segments I-VI: Setae 1,2-I,II slender, simple or double, occasionally 1-II triple; 6-I lengthy and strong, triple, unequal branches, one branch shorter; 6-II similar to 6-I, triple, occasionally with 4 branches; 6-III-V developed, with 3-7 aciculate branches; 6-VI with 3-5 
FORATTINI, O.P. \& SALLUM, M.A.M. A new species of Culex (Melanoconion) from Southern Brazil (Diptera: Culicidae). Rev. Saúde públ., S. Paulo, 19:171-82, 1985.

aciculate branches; 7-I lengthy, double, with subequal branches; 7-II-V slender, with 5-13 branches; 7-VI with 5-8 branches; 1 -III-VI with 7-12 strong branches; 13-III-V developed, with 6-10 branches. Segment VII: Seta 1-VII developed, with 5-12 branches; 4-VII slender, with 3-4 branches; 7-VII slender, with 4-8 branches; 10-VII triple occasionally with 4 branches; 13-VII developed, with 9-13 branches occasionally with fewer, until 4-5 branches. Segment VIII: Seta 1-VIII with 5-8 heavily aciculate branches; 2VIII slender and lengthy, double or triple; 3-VIII with 7-9 heavily aciculate branches; 4-VIII lengthy and simple; 5-VIII with 7-9 strong branches. Comb with 38-56 scales arranged in 4 roughly irregular rows, the anterior scales shorter than the posterior ones; scales normally fringed on sides and apex, apically more distinct than on the side; comb forming a whole nearly triangular outline, with the integument more chitinized and covered with patches of tiny spicules giving to the region an striated aspect. Siphon. - Index 5.8-8.3 (width measured at base); acus and basal ring heavily pigmented, the rest with lightly diffused pigmentation; acus length and narrow. Pecten of 9-12 spines increasing in size from base of siphon, distal ones a little more spaced; ventral margin of spines occupied by a larger basal tooth, following by a series of little teeth resulting in a whole nearly triangular outline, with formed by 6 pairs of multiple setae and 1 pair of simple ones; the first four basal 1-S with length a little more than width of siphon at point of insertions, the others with length less than width of siphon at point of insertion; 2-S inserted in membrane near base of anterolateral spiracular lobe, curved ventrally with slender secondary spiny submedian branch. Segment $X$. - Saddle complete, without acus and spicules; length 0.30$0.37 \mathrm{~mm}$; siphon/saddle index 3.8-4.3. Seta 1-X with 3-7 branches; $2-\mathrm{X}$ with
5 branches, one of them longer than the others; 3-X simple and lengthy; 4-X with 6 paired setae, 3 anterior pairs with 5-10 branches, 3 posterior ones with 8-11 branches, all setae borne on grid anteriorly attached to saddle. Anal papillae long and slender, a little more length than the saddle.

MATERIAL EXAMINED. - The specimens examined numbered 145 related as follows. Holotype. - Female with associated larval and pupal exuviae, collected in the Experimental Station of the Ribeira Valley, Pariquera-Açú County, S. Paulo State, Brazil, 5.IV.1984, Coll. O.P. Forattini and C. Casanova, as a larva from a ditch in open land with semipermanent fresh water, covered by molasses grass, at an elevation of $26 \mathrm{~m}$, deposited in the Entomological Collection of the Department of Epidemiology of the School of Public Health, University of S. Paulo, Brazil (FSPUSP), (n. E-6879). Paratypes. - 55 males ( 2 with larval and pupal exuviae), 76 females (5 with larval and pupal exuviae), 2 larvae, from several localities of S. Paulo State, Brazil. Deposited in the FSP-USP (ns. E-6880 to 6976): 2 males with associated larval and pupal exuviae (Itapuã, Cananéia, III.82. 1 ô ; Experimental Station, Pariquera-Açú, IV .84, 1 §), 18 males (Experimental Station, Pariquera-Açú, I. III, IV, V, XI. 79, I,XI.80, 11 o $\delta$; Ariri, Cananéia, III.79, 1 ๙ ; Pariquera-Açú, urban area, III. 79, 1 ơ : Taquari, Cananéia, I.80, 1 đ; Itapuã, Cananéia, IV .81, 1 sి; Biguá Road, Iguape, X.82, $1 \hat{s}$; Jacaré-Pipira, Dourado, VII. 80, I.81, 2 of $\delta$ ); 3 females with associated larval and pupal exuviae (Biguá Road, Iguape, III.84, 2 \& \%; Expeperimental Station, Pariquera-Açú, IV.84, 1 ₹), 20 females (Experimental Station, Pariquera-Açú, III, VII, VIII, X, XI, XII. 78, I, II, VII, VIII, X.79, II, VI.80, 14 \& \&; Jacaré-Pipira, Dourado, IV .80, VII. 82, 3 $\%$; Fazenda Lupo, Araraqua- 
FORATTINI, O.P. \& SALLUM, M.A.M. A new species of Culex (Melanoconion) from Southern Brazil (Diptera: Culicidae), Rev. Saúde públ., S. Paulo, 19:171-82, 1985.

ra, V, XI.81, 2 \&; Biguá Road, Iguape, IX. 92, 1 \%), 2 larvae (Experimental Station, Pariquera-Açú, II.85). Deposited in the National Museum of Natural History, Smithsonian Institution, Washington, D.C.: From the Experimental Station, Pariquera-Açú, 5 males (I, III. 79), 1 female with associated larval and pupal exuviae (IV.84), 5 females (V, XII. 79, 2 \% ; VI. 80, 1 \%; VII. 80, 2 ( )). Deposited in the British Museum (Natural History): From Experimental Station, Pariquera-Açú, 3 males (III. 79), 2 of $\delta$; V.79, 1 b), 1 female with associated larval and pupal exuviae (IV.84), 5 females (V, XII.79, VI.80, 3 \%; VII.80, $2 \%$ ), from Ariri, Cananéia, 2 males (III.79). Deposited in the "Instituto Oswaldo Cruz, Departamento de Entomologia", Rio de Janeiro, RJ: From the Experimental Station, Pariquera-Açú, 5 males (V.79, 3 of of; IX, X.79), 5 females (IX.78; X.78, 2 우; XII.79; II. 81). For exchange: 20 males (Experimental Station, Pariquera-Açú, XII .78, I, II, III, IV, V, VI.79, III. 80, IV . 82, 14 ồ; Ariri, Cananéia, III. 79, 1 \$ ; Jacaré-Pipira, Dourado, V, VI.80, I, II. 81,5 f $\delta$ ), 36 females (Experimental Station, Pariquera-Açú, IX, X, XI, XII . 78, I, II, V, VIII, X, XII.79, I, II, VII. 80, III, VII. 81,30 \&; Jacaré-Pipira, Dourado, X, XII.80, V.81, $3 \%$; Fazenda Lupo, Araraquara, XII.81, II. $82,3 \%$ \%). Other specimens. -2 females (Jacarepaguá, Rio de Janeiro State, Brazil, R.L. Oliveira col. X.82); $C x$. adamesi, 1 male Paratype (Panamá, 63), 2 males (Belém, 49), 2 females (Colombia); $C x$. crybda, 2 males (Panamá, 63), 1 female (Panamá, 63), 1 female (Trinidad, 63/64).

\section{DISTRIBUTION AND BIONOMICS.} - Culex ribeirensis seems to be widespread in the Southern Brazil Region. Probably it extends as far as the geographical area of the Tropical Atlantic System. It was found in several localities of S. Paulo State, being quite commonly found in regions near the Atlantic Coast and at low elevations above sea level. The finding of this mosquito in the coast areas of Rio de Janeiro State too, seems to support this hypothesis.

Adults show some degree of anthropophilic habits, and the species was usually found near human settlements in the modified environment. Up to the present breeding places have been found in these situations, constantly associated with densely grown land vegetation, such as grasses and several hydrophyte or aquatic plants (Fig. $1 \mathrm{~K}$ ). In these places water is usually fresh and shaded.

DISCUSSION. - Culex ribeirensis was early confused with $C x$. crybda. Nevertheless, it may be distinguished by the characteristic patch of clear scales found on the superior mesokatepisternum, absent in crybda. It may be separated from $C x$. epanastasis and $C x$. pedroi by the entirely dark aspect of the tarsi in ribeirensis, contrasting with the white ring pattern present in the hind tarsomeres 1-4 joints and the entire 5 hind one, found in that species. Beside this, there are accentuated differential characters with epanastasis, related to the morphology of male genitalia, as the lateral process of the aedeagal lateral plate, who is simple and lengthy in ribeirensis, and the peculiar aspects of distal division of the subapical lobe. Cx. adamesi may be distinguished from it by the forked scales of vertex, forming a whole clear in its central part and dark in the posterolateral one, while it is entirely dark in ribeirensis.

About the pupa, seta $10-\mathrm{CT}$ in adamesi, crybda and pedroi appears as fanlike with simple branches, contrasting with the fanlike aspect but with dendritic branches in ribeirensis. Besides that, in pedroi this seta usually shows a higher number of branches, sometimes reaching the double of those found in ribeirensis. 
FORATTINI, O.P. \& SALLUM, M.A.M. A new species of Culex (Melanoconion) from Southern Brazil (Diptera: Culicidae). Rev. Saúde públ., S. Paulo, 19:171-82, 1985.

The seta 6-III-VI is usually double in ribeirensis and simple in crybda. Setae 1-III-V are fanlike usually bearing a higher number of branches in ribeirensis (5-11) than in crybda (3-6). Seta 9-VII is developed, simple in ribeirensis and adamesi but double in pedroi, while the 9 . VIII is also developed simple in ribeirensis, but double in adamesi and pedroi. As for crybda, both these setae are slender, shorter and double or triple.

The larva of ribeirensis can be distinguished mainly by the aspect of setae 4-C and $1-\mathrm{M}$, which are fanlike, the first one with 3-5 simple branches, the second with 5-11 aciculate branches. In adamesi, crybda and pedroi the 4-C is forked, double or with a slightly larger number of branches, while the $1-\mathrm{M}$ is minute, simple and inconspicuous. Seta $1-\mathrm{T}$ is 3,4 branched in ribeirensis, simple minute in adamesi, crybda and pedroi. Seta 13-T is similar to $1-\mathrm{M}$ in ribeirensis while, though fanlike too, in adamesi and crybda presents simple, slender and shorter branches. Beyond that, setae 2,3-C are present in crybda, while $2-\mathrm{C}$ is absent in adamesi and ribeirensis.

FORATTINI, O.P. \& SALIUM, M.A.M. [A new species of Culex (Melanoconion) from Southem Brazil (Diptera: Culicidae)]. Rev. Saúde públ., S. Paulo $19: 171-82,1985$.

ABSTRACT: A new species from Southern Brazil, named Culex (Melanoconion) ribeirensis is described. The description includes adults, pupal and larval stages, illustrating the morphological aspects and a picture of a breeding place. Some data about known distribution and bionomics are presented.

UNITERMS: Culex (Melanoconion) ribeirensis. Culex. Insect vectors.

\section{REFERENCES}

1. FORATTINI, O.P. et al. Observações sobre atividade de mosquitos Culicidae, em mata residual do Vale do Ribeira, São Paulo, Brasil. Rev. Saúde públ., S. Paulo, 15:557-86, 1981

2. HARBACH, R.E. \& KNIGHT, K.L. Taxonomists glossary of mosquito anato $m y$. Marlton, NJ, Plexus Publishing, 1980.

3. ARBACH, R.E. et al. A new species of Culex (Melanoconion) from Southern America (Diptera, Culicidae). Mosq. Syst., 16:185-200, 1984.
4. OLIVEIRA, R.L. de Alguns aspectos da ecologia de mosquitos (Diptera: Culicidae) de uma área de planície (Granjas Calábria), em Jacarepaguá, Rio de Janeiro. I. Frequiência comparativa das espécies em diferentes ambientes e métodos de coleta. Mem. Inst. Oswaldo Cruz, Rio de Janeiro, 79:479-90, 1984.

5. SIRIVANAKARN, S. \& JAKOB, W.L. A new species of Culex (Melanoconion) from Southern Brazil (Diptera:Culicidae). Mosq. Syst., 11:139-43, 1979.

Received for publication in 28/03/1985 Accepted for publication in 02/04/1985 
FORATTINI, O.P. \& SALLUM, M.A.M. A new species of Culex (Melanoconion) from Southern Brazil (Diptera: Culicidae). Rev. Saúde públ., S. Paulo, 19:171-82, 1985.

Fig. 1 - Female: A and B - dorsal aspect of head showing falcate and forked scales; $C$. dorsal aspect of cibarial armature; $D$. detail of figure $C$ focusing the cibarial teeth; $\mathbf{E}$ - posterodorsal aspect of cibarial armature; $\mathbf{F}$ - detail of figure $\mathbf{E}$ focusing the cibarial teeth; $G$ - dorsal aspect of distal right wing scaling: $H$ - aspect of the lateral right side of thorax showing upper mesokatepisternal scale patch; I - detail of figure $H$ focusing the upper mesokatepisternal scales; $J$ - ventral aspect of distal right wing scaling.

Collection place: $\mathbf{K}$ - environmental view of the locality in Iguape County, S. Paulo State, Brazil, where immature stages were collected. Breeding places were found in the lateral road ditches, densely covered by molasses grass and situated near to human settlements.

Figs. 2-4 - Abreviations used:

a - seta a of pSI

A - antenna

Aes - aedeagal sclerite

$b$ - seta $b$ of pSL

$\mathrm{BP}$ - basal piece

C - cranium

CA - cibarial armature

$\mathrm{Cir}$ - cercus

$\mathrm{CS}$ - comb scale

$\mathrm{CSc}$ - cercal sclerite

Ct - cibarial tooth

CT - cephalothorax

Dm - dorsomentum

dSL - distal division of subapical lobe

$f$ - flat seta of dSL (= foliform)

Gc - gonocoxite

Gs - gonostylus

$\mathrm{h}$ - hooked seta of asL

IsS - insular seta

LP - lateral plate

M - mesothorax

MPlp - maxillary.palpi

p - puncture

$P$ - prothorax

$\mathrm{Pa}$ - paddle

Par - paramere

PGL - postgenital lobe

Ppr - paraproct

PS - pecten spine

pSL - proximal division of subapical lobe

s - saberlike seta of dSL (= saber)

S - siphon

T - metathorax

Tr - trumpet

UVL - upper vaginal lip

UVS - upper vaginal sclerite

I-IX - abdominal segments

VIII-Te - tergum VIII

IX-Te - tergum IX

IX-TL - ninth tergal lobe

$\mathrm{X}-\mathrm{Te}-$ tergum $\mathrm{X}(=$ basolateral sclerotization $)$ 
FORATTINI, O.P. \& SALLUM, M.A.M. A new species of Culex (Melanoconion) from Southern Brazil (Diptera: Culicidae). Rev. Saúde públ., S. Paulo, 19:171-82, 1985.

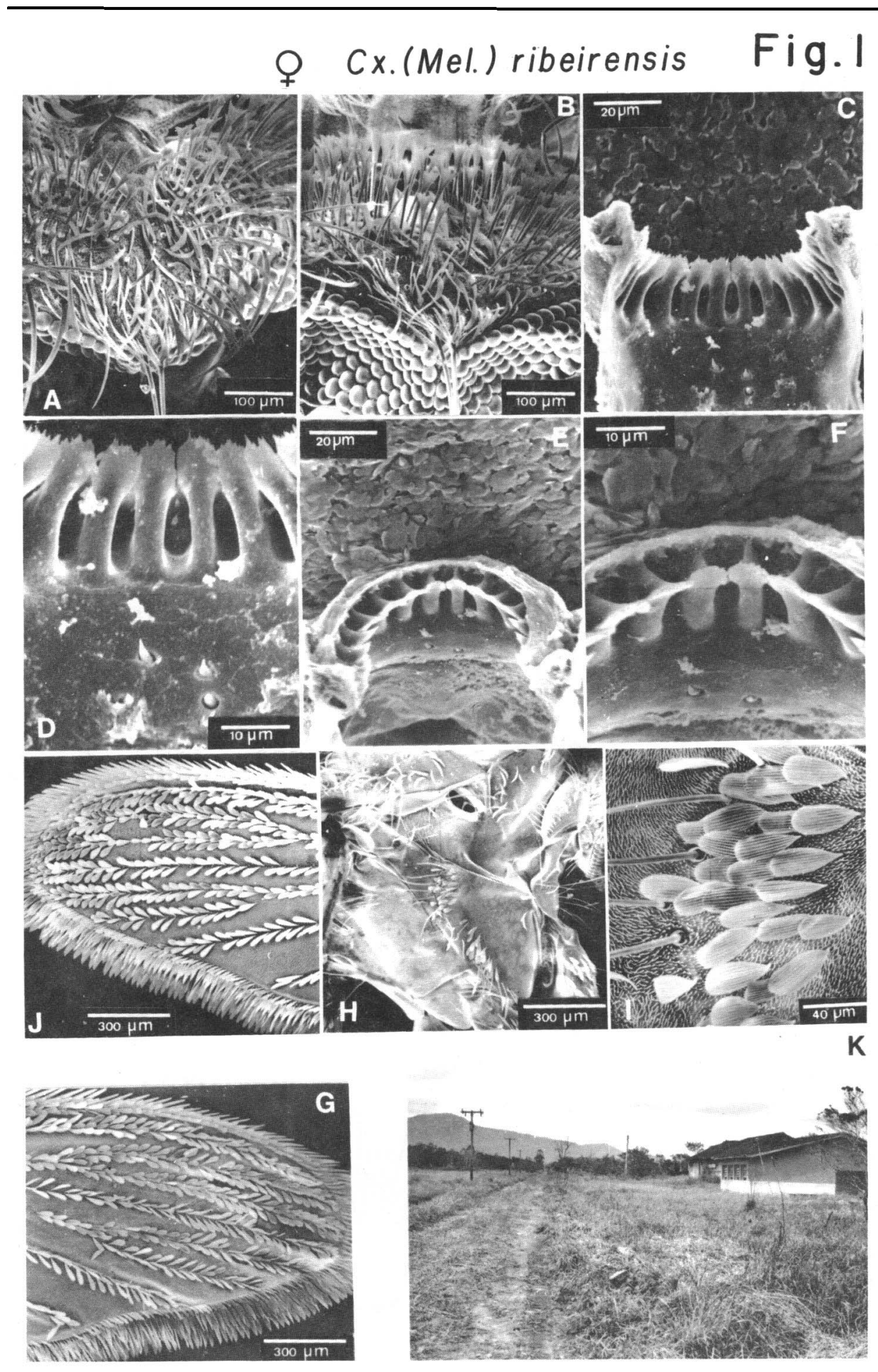


FORATTINI, O.P. \& SALLUM, M.A.M. A new species of Culex (Melanoconion) from Southern Brazil (Diptera: Culicidae). Rev. Saúde públ., S. Paulo, 19:171-82, 1985.
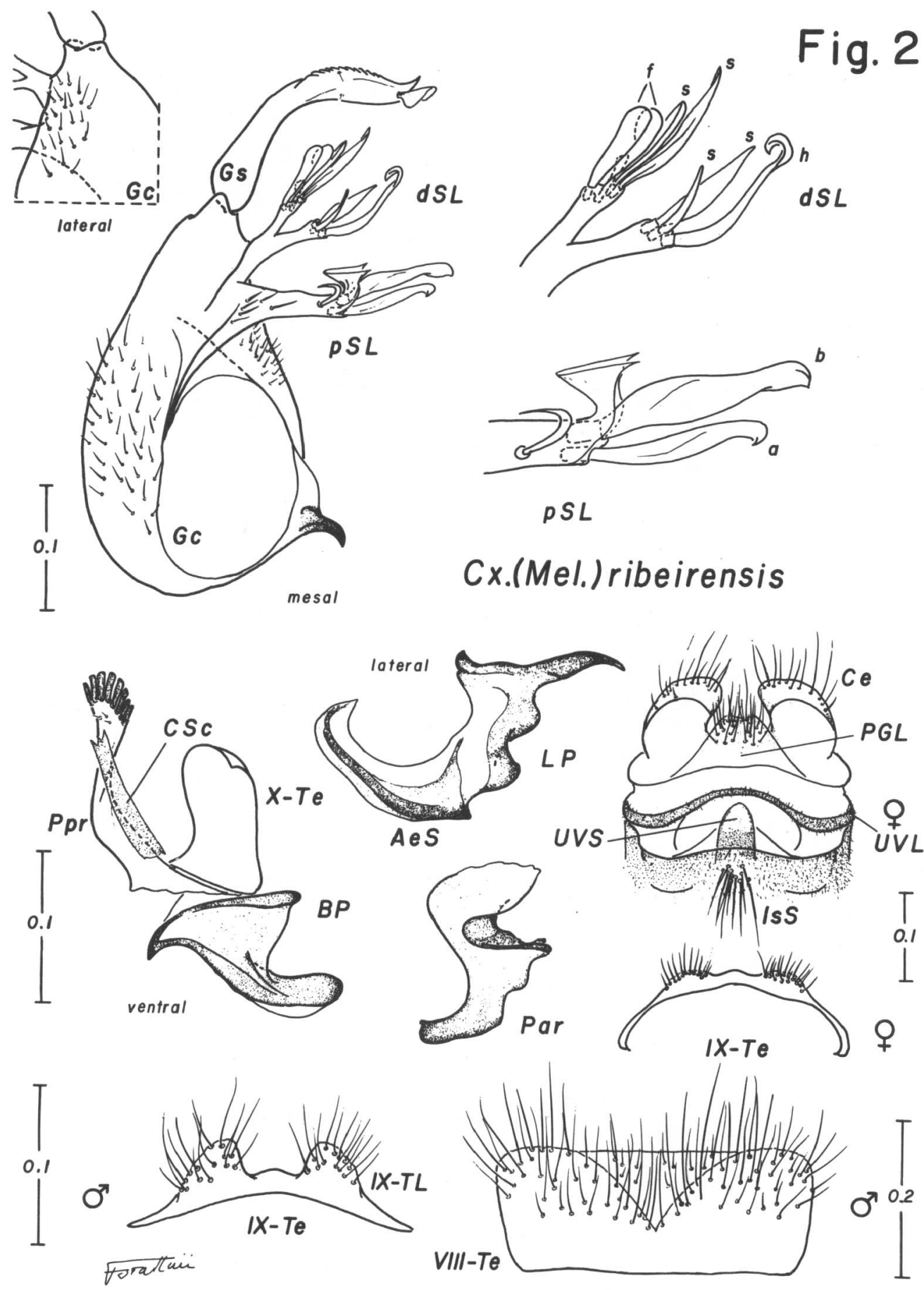
Fig. 3

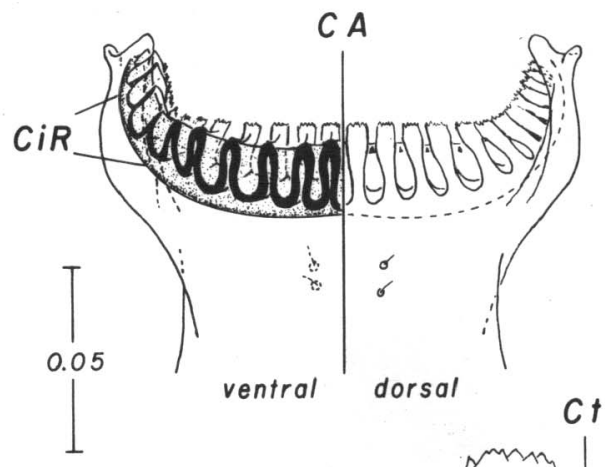

\section{$C A$}
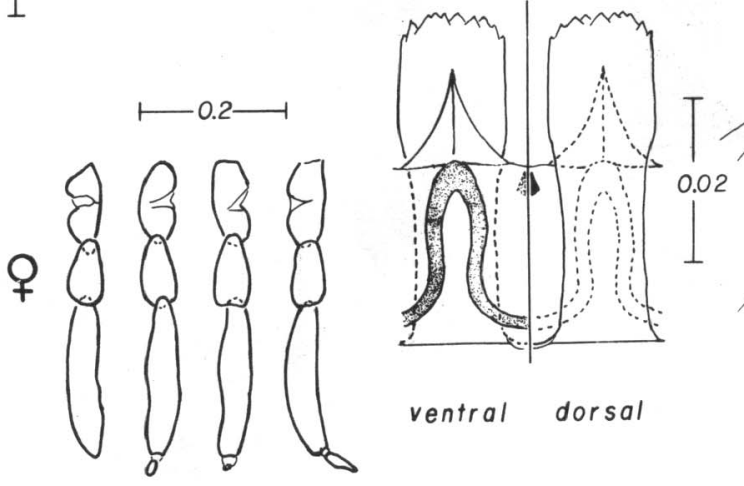

ventral dorsal

MPIP

Cx.(Mel.) ribeirensis

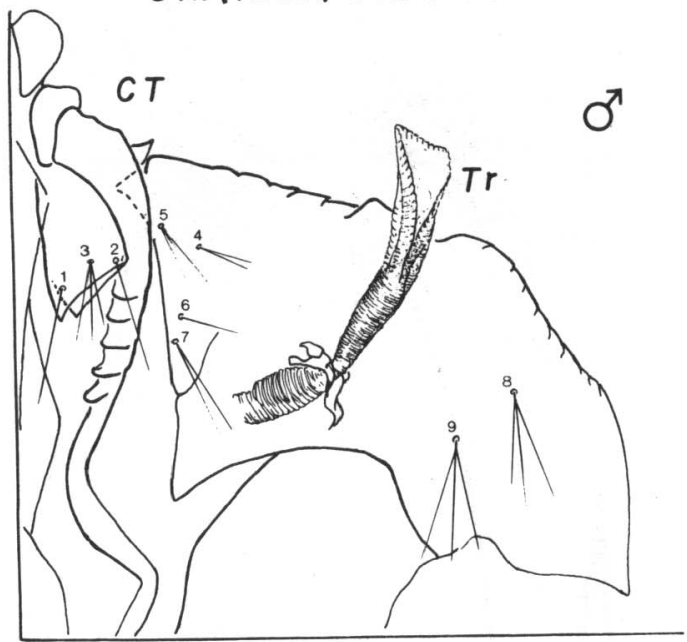

1.0
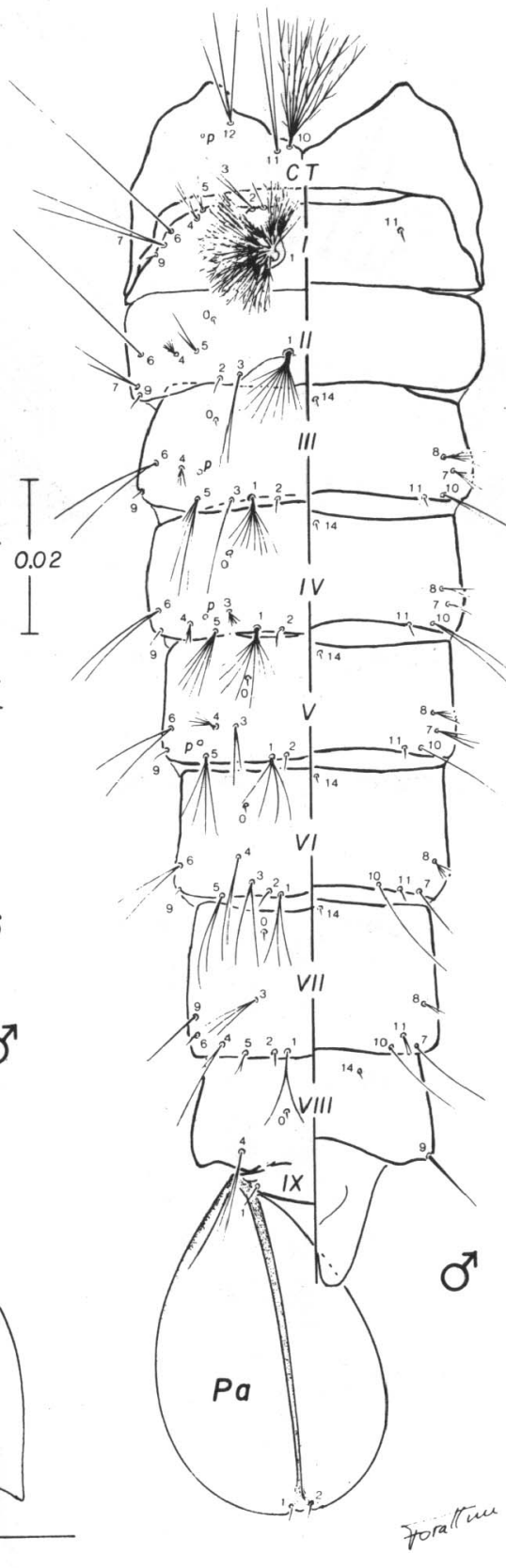

$\longmapsto 0.5 \longrightarrow$ 
Fig. 4

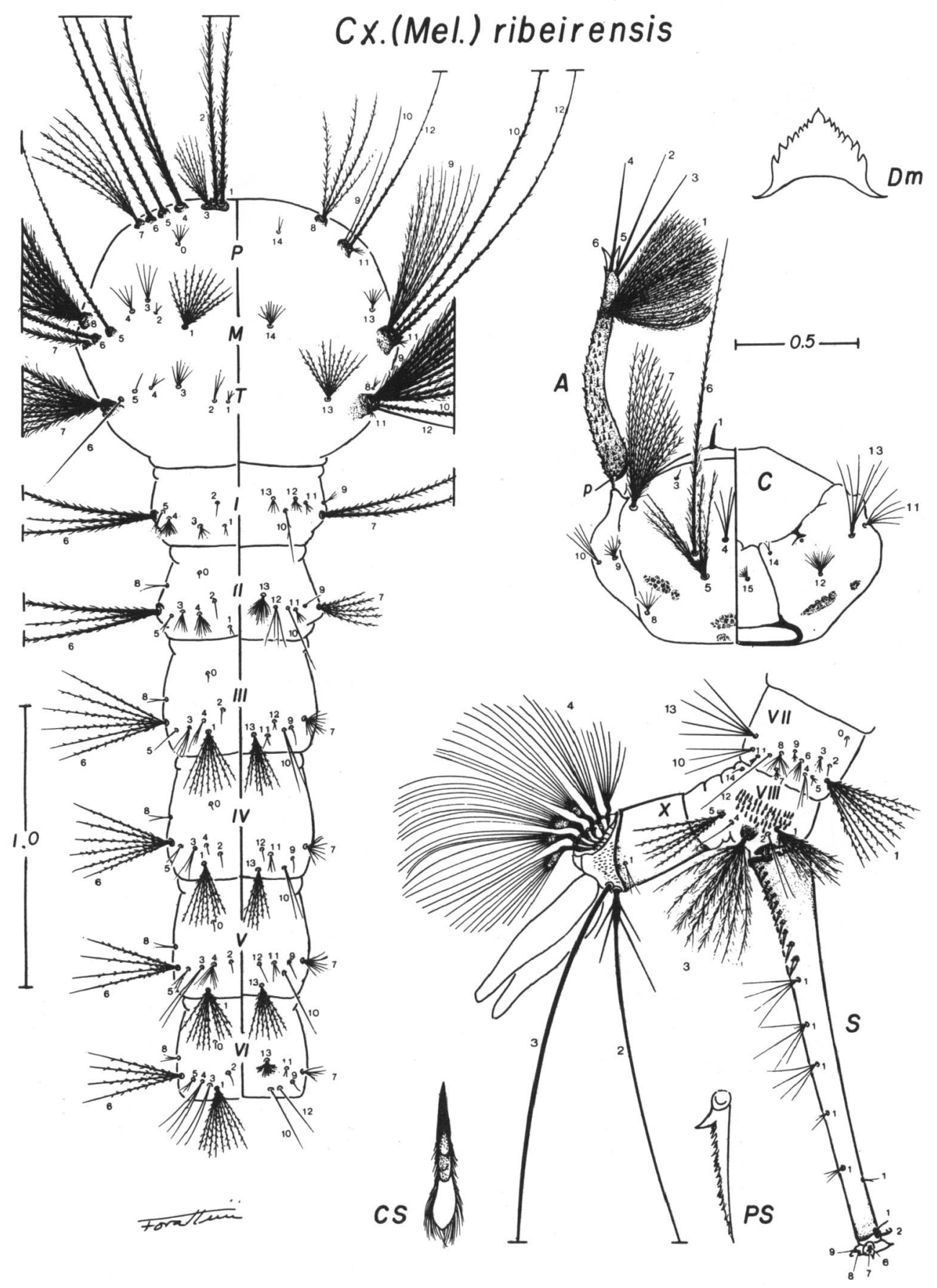

